\title{
Analysis of Helper Activity on Pokeweed Mitogen- and Interleukin 2-driven Immunoglobulin Synthesis by Neoplastic $\mathrm{T4}^{+}$Cells
}

\author{
Frank Miedema, Johan W. van Oostveen, Fokke G. Terpstra, A. Warmold L. van den Wall Bake, Rein Willemze, \\ Erik A. J. Rauws, Rob Bieger, Mars B. van 't Veer, Daniel Catovsky, and Cornelis J. M. Melief \\ Central Laboratory of the Netherlands Red Cross Blood Transfusion Service, Incorporating the Laboratory for Experimental and Clinical \\ Immunology of the University of Amsterdam. The Netherlands; Department of Nephrology and Department of Dermatology, \\ University Hospital, Leiden, The Netherlands; Department of Internal Medicine, Bronovo Hospital, The Hague, The Netherlands; \\ and Royal Post Graduate Medical School, London, United Kingdom
}

\begin{abstract}
The neoplastic $\mathbf{T}$ cells of a series of seven patients with chronic T-cell neoplasia were tested for helper activity on pokeweed mitogen (PWM)-induced and interleukin 2 (IL-2)-induced Ig synthesis. The neoplastic $\mathrm{T}$ cells of all patients had a $\mathrm{T3}^{+} 4^{+} 8^{-} 11^{+} \mathrm{II}^{-}$ phenotype but differed in expression of the 3A1 antigen. The neoplastic $\mathrm{T}$ cells of three patients had helper activity on both PWM- and IL-2-driven Ig synthesis, and in addition produced IL-2 in response to PWM stimulation. Two of these patients had hypergammaglobulinemia. In contrast, the neoplastic $T$ cells in the remaining four patients did not produce IL-2 and did not support PWM-driven Ig synthesis. The $\mathrm{T4}^{+}$cells of these four patients, however, provided excellent helper activity on IL-2driven Ig synthesis. These findings emphasize the role of IL-2 in $T$ cell-dependent Ig synthesis and clearly show that IL-2 production is required for helper activity in the PWM-driven system. It is concluded that the combined use of PWM- and IL-2-driven Ig synthesis systems allows separate analysis of IL-2 production and $\mathrm{T}$-helper activity in health and disease.
\end{abstract}

\section{Introduction}

The rationale for functional studies with neoplastic $T$ cells in human proliferative diseases is dual: in the first place, they may contribute to a refined classification of the various lymphoproliferative disorders. Second, the malignant cells may represent homogeneous outgrowths of $\mathrm{T}$ cells that to a greater or lesser extent have retained the functional properties and phenotype of the normal counterpart $T$-cell subset. Clonal expansions of $T$ cells with a mature helper phenotype in Sézary syndrome patients and in some patients with chronic T-cell lymphocytic leukemia $(T-C L L)^{1}$ have been reported. In only a small number of patients

Address all correspondence to Dr. Frank Miedema, Central Laboratory of the Netherlands Red Cross Blood Transfusion Service, P.O. Box 9406, 1006 AK Amsterdam, The Netherlands.

Received for publication 7 May 1985.

1. Abbreviations used in this paper: ATLL, adult T-cell lymphoma/leukemia; BM, bone marrow; CLL, chronic lymphocytic leukemia; CTCL, cutaneous T-cell lymphoma; E, sheep erythrocytes; IL-2, interleukin 2; LFA-1, lymphocyte function-associated antigen-1; LN, lymph nodes; PBL, unfractionated peripheral blood leukocytes; PLL, prolymphocytic leukemia; PWM, pokeweed mitogen.

J. Clin. Invest.

(c) The American Society for Clinical Investigation, Inc. $0021-9738 / 85 / 12 / 2139 / 05 \$ 1.00$

Volume 76, December 1985, 2139-2143 the $\mathrm{T}^{+}$cells had functional helper activity on pokeweed mitogen (PWM)-driven Ig synthesis (1-5). Although the neoplastic T cells in adult T-cell lymphoma/leukemia (ATLL) patients have the helper $\mathrm{T} 4^{+} 8^{-}$phenotype, the malignant $\mathrm{T}$ cells lack helper activity, and in a large number of patients have suppressor activity (5-7).

It has been demonstrated that interleukin 2 (IL-2) plays an important role in T-cell-dependent Ig synthesis $(8,9)$. IL-2 production is a requirement for PWM-induced Ig synthesis (8) and moreover, IL-2 itself induces Ig synthesis in a T-cell-dependent fashion $(8,9)$. In the IL-2-driven system, the necessity of IL-2 production by $\mathrm{T}$-helper cells is bypassed by the addition of exogenous IL-2. Analysis of helper activity in both the PWM- and the IL-2-driven system enables one to study separately two Tcell functions required for helper activity on B-cell differentiation: IL-2 synthesis and the delivery of the actual T-helper signal induced by IL-2. In contrast to "bulk" $\mathrm{T} 4^{+}$populations, clonal $\mathrm{T}^{+}$cells, derived from normal individuals in vitro (10) and from "clonal" neoplastic $\mathrm{T}^{+}$cells of patients with mature $\mathrm{T}$ cell malignancies (11), do not always produce IL-2 upon stimulation. In the present study, helper activity on PWM- and IL2 -driven Ig synthesis delivered by the neoplastic $\mathrm{T}^{+}{ }^{+}$cells from a series of seven patients was evaluated. In three patients, the neoplastic $\mathrm{T}^{+}$cells had helper activity in both systems. Neoplastic $\mathrm{T}^{+}$cells of four patients did not show helper activity on PWM-driven Ig synthesis, but provided excellent help on IL-2induced Ig synthesis. The capacity to provide help on PWMinduced Ig synthesis correlated well with the capacity to produce IL-2 in response to PWM. None of the latter four tumor cell populations produced IL-2 upon PWM stimulation. Helper activity and IL-2 production in vitro was associated with hypergammaglobulinemia in two out of three patients.

\section{Methods}

Patients. The main clinical findings of the patients are summarized in Table I. All patients had very high white blood cell counts. The majority of the white cells were lymphocytes. In all patients the disease had a progressive course and, as of this writing, all patients, except patient 6 , have died. Hypergammaglobulinemia existed in patients 2 and 3. AntiHTLV-I antibodies were not detected in patient sera in an indirect immunofluorescence test on HTLV-I-positive MJ2 C10 cells (kindly provided by Dr. R. C. Gallo, National Cancer Institute, Bethesda, MD). At the time of blood sampling the patients were not treated with cytoreductive drugs.

Cell preparation. Peripheral blood mononuclear cells (PBL) of normal donors and patients were isolated by Ficoll-Isopaque density gradient centrifugation of anticoagulated or defibrinated blood. $T$ and non- $T$ cells were separated by sheep erythrocyte $(E)$ rosette sedimentation using neuraminidase-treated sheep red blood cells (12) and cryopreserved by 
Table I. Main Clinical Findings in Seven Patients With $\mathrm{T4}^{+}$Neoplasia

\begin{tabular}{|c|c|c|c|c|c|c|c|c|c|c|c|c|c|}
\hline \multirow{2}{*}{$\begin{array}{l}\mathrm{Pa}- \\
\text { tient }\end{array}$} & \multirow{2}{*}{$\begin{array}{l}\text { Age/ } \\
\text { sex }\end{array}$} & \multirow{2}{*}{$\begin{array}{l}\text { Leuko- } \\
\text { cytes }\end{array}$} & \multirow{2}{*}{$\begin{array}{l}\text { Lympho- } \\
\text { cytes }\end{array}$} & \multicolumn{4}{|c|}{ Infiltrations* } & \multicolumn{3}{|c|}{ Immunoglobulin levels (IU)‡ } & \multirow[b]{2}{*}{ Other symptoms } & \multirow[b]{2}{*}{ Diagnosis } & \multirow{2}{*}{$\begin{array}{l}\text { Survival } \\
\text { time from } \\
\text { diagnosis }\end{array}$} \\
\hline & & & & BM & $\mathrm{Li}$ & $\mathrm{Spl}$ & $\mathrm{LN}$ & $\lg M$ & IgG & $\operatorname{Ig} A$ & & & \\
\hline & & $\times 10^{-9} /$ /iter & $\%$ & & & & & & & & & & mo \\
\hline $1 \mathrm{Al}$ & $66 / F$ & 400 & 90 & + & - & + & - & $\mathrm{N}$ & $\mathrm{N}$ & $\mathrm{N}$ & Edema & T-PLL & 12 \\
\hline $2 \mathrm{La}$ & $57 / \mathrm{M}$ & 285 & 90 & + & + & + & + & 1,040 & $\mathrm{~N}$ & $\mathrm{~N}$ & Ascites & T-PLL & 2 \\
\hline $3 \mathrm{Va}$ & $80 / \mathrm{M}$ & 29.7 & 50 & + & - & - & + & $\mathrm{N}$ & 350 & 1,180 & $\begin{array}{l}\text { Erythroderma, } \\
\text { skin lesions }\end{array}$ & T-CLL & 11 \\
\hline $4 \mathrm{Hi}$ & $75 / \mathrm{F}$ & 63.9 & 90 & + & + & + & + & $\mathrm{N}$ & $\mathrm{N}$ & $\mathrm{N}$ & Skin lesions & T-CLL & 10 \\
\hline 5 Sto & $75 / \mathrm{M}$ & 134 & 95 & + & + & + & + & $\mathrm{N}$ & $\mathrm{N}$ & $\mathrm{N}$ & & T-PLL & 8 \\
\hline $6 \mathrm{An}$ & $59 / \mathrm{M}$ & 21.7 & 65 & + & - & - & + & $\mathrm{N}$ & $\mathrm{N}$ & $450 \S$ & $\begin{array}{l}\text { Skin lesiions, } \\
\text { erythroderma }\end{array}$ & $\begin{array}{l}\text { Sézary } \\
\text { syndrome }\end{array}$ & $>24$ \\
\hline $7 \mathrm{Bo}$ & $67 / \mathrm{M}$ & 600 & 92 & + & - & - & + & $\mathrm{N}$ & $\mathrm{N}$ & $\mathrm{N}$ & Skin lesions & T-PLL & 10 \\
\hline
\end{tabular}

* BM, bone marrow; Li, liver; Spl, spleen; LN, lymph nodes. ‡ Normal range: IgM, 45-235 IU; IgG, 65-200 IU; IgA, 40-224 IU; N, within normal range. $\S$ Transiently elevated IgA levels.

standard procedures. $\mathrm{T}^{+}$and $\mathrm{T}^{+}$cells were separated by a negative "panning" technique on sheep anti-mouse Ig-coated petri dishes. $\mathrm{T}^{+}$ cells obtained from normal donors were $80 \% \mathrm{~T}^{+}$and $<5 \% \mathrm{~T}^{+}$as evaluated by indirect immunofluorescence with OKT4 and OKT8 monoclonal antibodies.

Surface marker analysis. Surface marker profiles of healthy donor PBL and patient PBL were determined by indirect immunofluorescence with the following monoclonal antibodies: OKT1, OKT3, OKT4, OKT6, OKT8, OKT11, OKT17, OKI1 (13-15), 3A1 (16), and CLB-LFA-1/1, an anti-lymphocyte function associated antigen-1 (LFA-I) antibody (17), and FITC-conjugated goat anti-mouse IgG (Central Laboratory of the Netherlands Red Cross Blood Transfusion Service, Amsterdam, The Netherlands). Cytofluorometric analysis was performed on a cytofluorograph (model FC-200; Ortho Diagnostics, Raritan, NJ).

Assay of helper activity on in vitro B-cell differentiation. Helper activity of normal $\mathrm{T}^{+} \mathrm{T}$ cells and neoplastic $\mathrm{T} 4^{+}$cells of the patients was tested in a PWM-driven Ig synthesis system described in detail before (18). Graded numbers of $\mathrm{T}^{+}$cells and PBL of the patients were co-cultured with $2-4 \times 10^{4}$ normal non-T cells in the presence of $50 \mu \mathrm{g} / \mathrm{ml} \mathrm{PWM}$ (Gibco, Grand Island, NY; lot no. C477102). In the same microculture system it has been shown that optimal concentrations $(30 \mathrm{U} / \mathrm{ml})$ of purified IL-2 and human recombinant IL-2 induce Ig synthesis in a T-celldependent fashion quite similar to the PWM-driven helper system $(8$, 9). Patient cells were tested for helper activity in this system as well. The culture medium was Iscove's modified Dulbecco's medium supplemented with $20 \%$ fetal calf serum (Gibco; cat. No. $629 \mathrm{HI}$ ) and antibiotics. All cultures were set up in quadruplicate in $170 \mu \mathrm{l}$ of medium. IgM and IgG were measured in pooled supernatants after $7 \mathrm{~d}$ of culture using an en- zyme-linked immunosorbent assay. In some cultures IgA was determined by radioimmunoassay.

$I L-2$ production. The production of IL- 2 by normal control $\mathrm{T}^{+} \mathrm{T}$ cells and PBL of patients was evaluated under the same culture conditions as applied for the PWM-induced helper assays. After $3 \mathrm{~d}$ of culture, supernatants of quadruplicate cultures were pooled and stored at $-20^{\circ} \mathrm{C}$ until tested for IL-2 activity in a proliferation assay with an IL-2-dependent murine T-cell line as indicator cells. The amounts of IL-2 are expressed in units per milliliter, one unit being defined as the amount of IL-2 that induces half-maximal proliferation in the murine T-cell line.

\section{Results}

Surface marker analysis of patient lymphocytes. In all patients the malignant $\mathrm{T}$ cells in the blood were $\mathrm{T} 3^{+} 4^{+} 8^{-} 11^{+}, \mathrm{I1}^{-}$, LFA$1^{+} \mathrm{T}$ cells, except in patient 7 , whose neoplastic $\mathrm{T}$ cells did not express the $\mathrm{T} 3$ antigen (Table II). The majority of the $\mathrm{T} 4^{+}$cells of patient 3 (T-CLL) and patient 6 (Sézary syndrome) did not react with a monoclonal antibody that defines the $3 \mathrm{~A} 1$ antigen, an antigen that is characteristically not expressed on neoplastic $\mathrm{T}^{+}$cells in Sézary syndrome and ATLL patients (16). In the cases tested the tumor cells were $\mathrm{T}_{17^{+}}$, an antigen expressed on the majority of peripheral $\mathrm{T}$ cells (15). The homogeneous marker profiles taken together with the very high lymphocyte count in the patients indicate that the PBL of the patients were virtually all tumor cells.

Table II. Surface Marker Analysis of Neoplastic T Cells in Seven Patients

\begin{tabular}{|c|c|c|c|c|c|c|c|c|c|c|c|c|}
\hline \multirow[b]{2}{*}{ Patient } & \multirow[b]{2}{*}{ E-rosettes* } & \multicolumn{11}{|c|}{ Binding of monoclonal antibodies $\ddagger$} \\
\hline & & $\mathrm{Tl}$ & $\mathrm{T} 3$ & $\mathrm{~T} 4$ & T6 & T8 & $\mathrm{T} 11$ & $\mathrm{~T} 17$ & TAC & II & $3 \mathrm{Al}$ & CLB-LFA- $1 / 1$ \\
\hline 1 & 73 & NT & 88 & 84 & NT & 1 & 90 & NT & 29 & NT & NT & 96 \\
\hline 2 & 93 & 88 & 92 & 93 & NT & 8 & 93 & 87 & NT & 5 & 94 & 95 \\
\hline 3 & NT & 97 & 93 & 90 & 6 & 10 & 84 & 85 & NT & 9 & 21 & 70 \\
\hline 4 & 46 & 89 & 95 & 95 & 0 & 5 & 87 & 88 & 18 & 7 & 95 & 97 \\
\hline 5 & 98 & NT & 92 & 94 & 0 & 3 & 98 & NT & 27 & 2 & 79 & 98 \\
\hline 6 & NT & NT & 80 & 90 & 4 & 0 & 80 & 70 & NT & 4 & 6 & 90 \\
\hline 7 & 80 & 95 & 2 & 97 & 3 & 3 & 95 & NT & 25 & 0 & 97 & 79 \\
\hline
\end{tabular}

* Percentage of rosette-forming cells. $\ddagger$ Percentage of positive cells measured by cytofluorographic analysis. NT, not tested. 


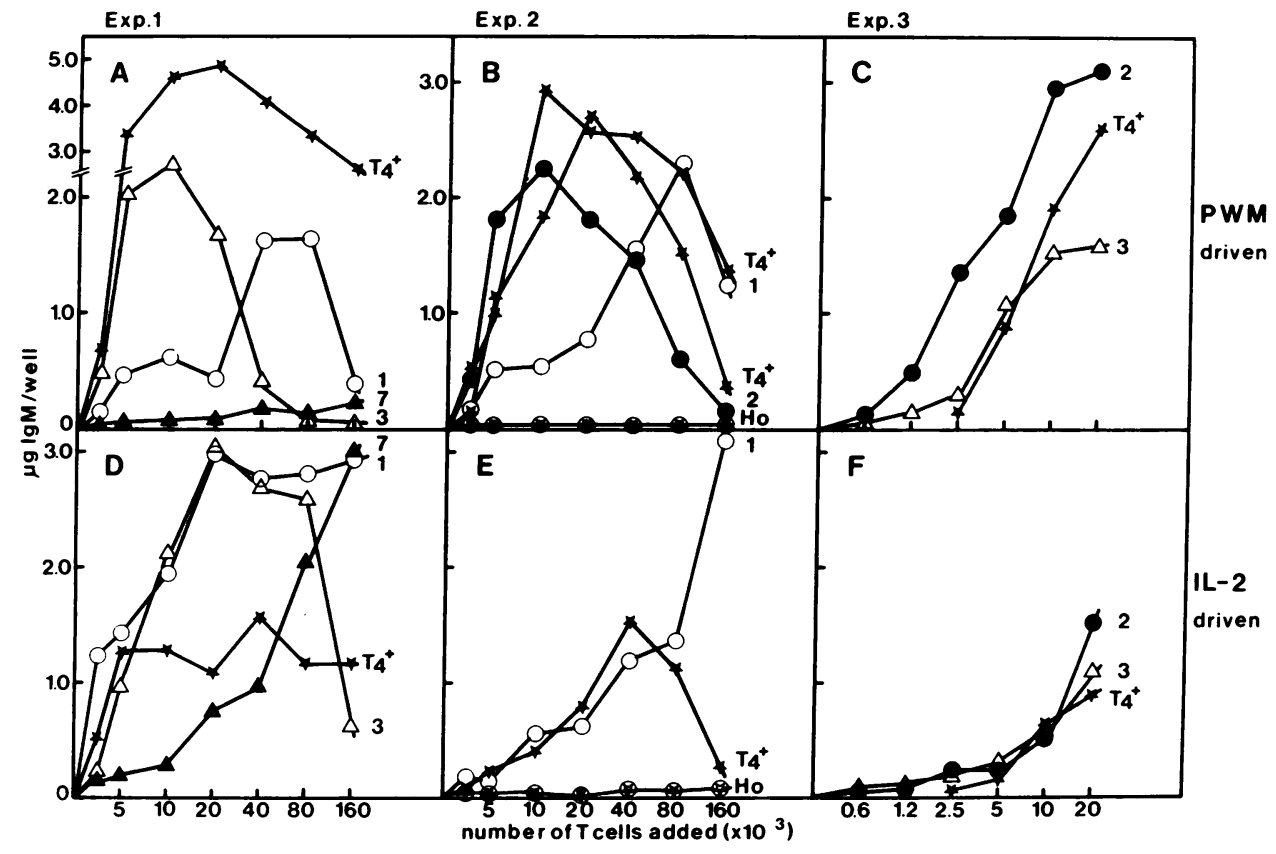

Figure 1. Helper activity of normal and neoplastic $\mathrm{T}^{+}$cells. Graded numbers of $\mathrm{T}^{+}$cells of patient 1 $(0), 2(\bullet), 3(\Delta), 7(\bullet)$, and Sézary syndrome patient Hoe (Reference 22) (ఉ), and normal T4 $4^{+}$cells $(\star)$, were added to $20-40,000$ non-T cells of a normal donor and cultured in the presence of PWM $(A-C)$ and IL-2 $(D-F)$. The results of three different experiments are shown $(A$ and $D, B$ and $E$, and $C$ and $F$ ).
Neoplastic $\mathrm{T4}^{+}$cells with helper activity on both PWM- and IL-2-driven Ig synthesis. The malignant T cells of three out of seven patients (patients 1, 2, and 3) provided helper activity on PWM- and IL-2-driven Ig synthesis. Fig. 1 shows the helper activity of graded numbers of PBL of patients 1,2, 3, and 7 in the PWM- and the IL-2-driven system compared with normal $\mathrm{T}^{+}$cells in three different experiments. The neoplastic $\mathrm{T}^{+}$cells of patient 2 were very potent as helper cells, because a shift towards lower cell numbers in the dose-response curve in the PWM-driven system was observed with patient cells compared with normal $\mathrm{T}^{+}$cells when very low $\mathrm{T}$ cell numbers were applied (Fig. 1, Exp. 3). Helper activity of $\mathrm{T}^{+}$cells of patient 1 showed an altered dose-response curve, with an optimal helper activity at high cell numbers, compared with normal $\mathrm{T}^{+}$cells and $\mathrm{T}^{+}$ cells of patients 2 and 3 (Fig. 1, Exp. 1 and 2). As controls, T4 ${ }^{+}$ cells of patient 7 and of a Sézary syndrome patient (Hoe) that have been shown to be devoid of helper activity in the PWM- induced system, were arbitrarily included (Fig. 1, Exp. 1 and Exp. 2). The $\mathrm{T}^{+}$cells of patient 7 , in contrast to the cells of patients $1-3$, only had helper activity in the IL-2-driven system (Fig. 1D).

Neoplastic $\mathrm{T4}^{+}$cells with helper activity on IL-2-driven Ig synthesis. The neoplastic $\mathrm{T}^{+}$cells of four out of seven patients (patients 4-7) in the present series did not provide or provided marginal (patient 5) helper activity on PWM-driven Ig synthesis, but provided good helper activity in the presence of exogenous IL-2 (Fig. 2). The results of at least three experiments demonstrate that the helper activity provided by the tumor cells of patients 4-7 reached its optimum at relatively high cell numbers (Fig. 2). For normal $\mathrm{T}^{+}$cells the optimal Ig induction was obtained by 20,000 or 40,000 cells (Figs. 1 and 2 ).

PWM-induced IL-2 synthesis by neoplastic $\mathrm{TH}^{+}$cells. Because IL-2 production is an essential step in PWM-induced Ig synthesis, it was then tested whether the neoplastic $\mathrm{T}^{+}$cells of these seven

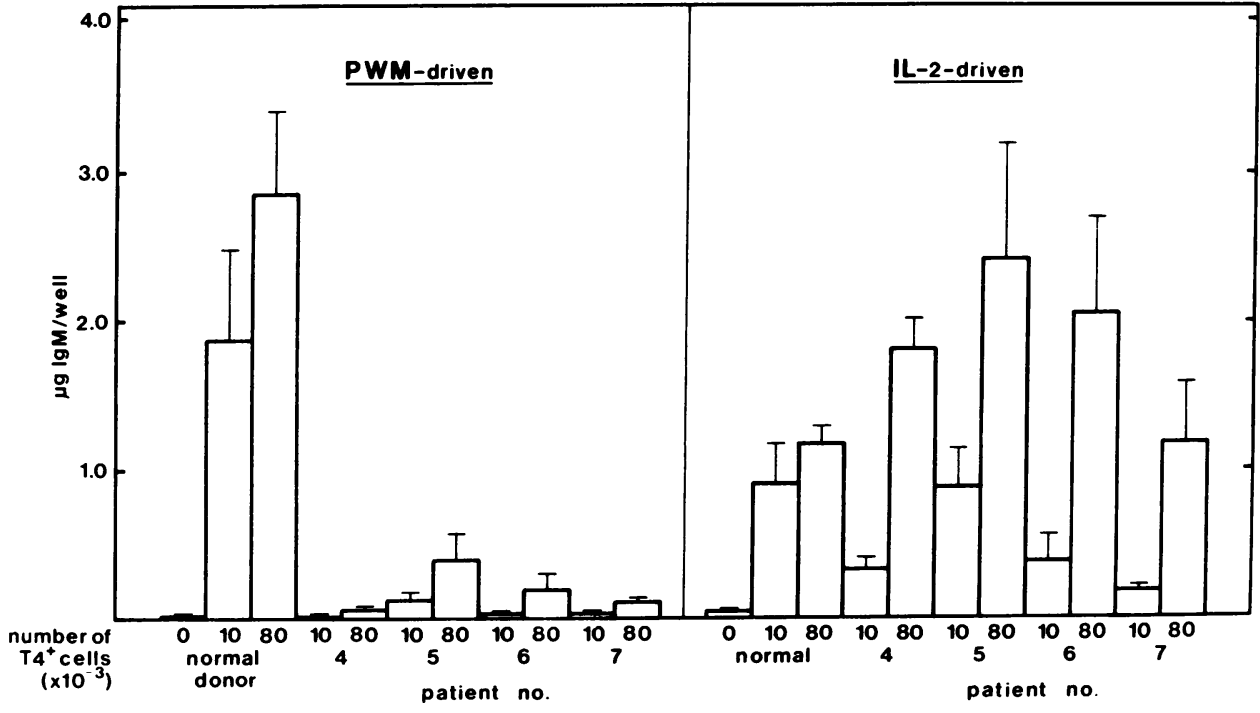

Figure 2. Neoplastic $\mathrm{T}^{+}$cells of patients 4-7 only have helper activity on IL-2-induced Ig synthesis. T4 ${ }^{+}$ cells of normal donors and of patients 4-7 were cultured with 20,000 normal non-T cells in the presence of PWM (left) and IL-2 (right). The mean and SD (in vertical bars) of at least three experiments are shown. IgM production (micrograms per well) induced by 10,000 and 80,000 $\mathrm{T4}^{+}$cells is shown. 


\begin{tabular}{|c|c|c|c|c|c|c|c|c|c|}
\hline \multirow[b]{4}{*}{ Patient } & \multirow[b]{4}{*}{ Exp. No. } & \multicolumn{8}{|c|}{$\mathrm{IL}-2(\mathrm{U} / \mathrm{ml})$} \\
\hline & & \multicolumn{4}{|c|}{ Normal donor $\mathrm{T}^{+}$} & \multicolumn{4}{|c|}{ Neoplastic $\mathrm{T}^{+}$} \\
\hline & & \multicolumn{4}{|c|}{ Cell number $\left(\times 10^{-3}\right)$} & \multicolumn{4}{|c|}{ Cell number $\left(\times 10^{-3}\right)$} \\
\hline & & 2.5 & 5 & 10 & 20 & 2.5 & 5 & 10 & 20 \\
\hline 1 & 1 & $2.3^{*}$ & 3.1 & 3.8 & 7.0 & 1.1 & 3.3 & 1.9 & 2.7 \\
\hline 2 & 1 & 2.5 & 4 & 7 & 8 & 1.3 & 2.5 & 4.3 & 16 \\
\hline \multirow[t]{4}{*}{3} & 1 & 2.5 & 4 & 7 & 8 & 2.5 & 3.8 & 8 & 12.5 \\
\hline & 2 & 2.3 & 3.1 & 3.8 & 7.0 & 2.1 & 2.1 & 5.5 & 8.1 \\
\hline & 3 & 2.3 & 3.1 & 3.8 & 7.0 & 3.8 & 4.6 & 11.5 & 9.7 \\
\hline & 4 & 1 & 1.5 & 2.0 & 2.5 & 3.5 & 9.5 & 20 & 35 \\
\hline
\end{tabular}

* IL-2 production in units per milliliter in the presence of 20,000 non-T cells and PWM after $3 \mathrm{~d}$ of culture.

patients in our series could produce IL-2 upon stimulation with PWM. Normal donor $\mathrm{T}^{+}$cells produced significant amounts in the PWM-driven system, with a peak response at day $3(8)$ (Table III). The neoplastic $\mathrm{T}^{+}$cells of patients 2 and 3 produced large amounts of IL-2, whereas the $\mathrm{T} 4^{+}$cells of patient 1 produced amounts of IL-2 comparable to the amount of IL-2 produced by normal $\mathrm{T}^{+}$cells (Table III). $\mathrm{T}^{+}$cells of patients $4-$ 7 never produced more than $1 \mathrm{U} / \mathrm{ml}$ (data not shown).

\section{Discussion}

Functional studies with neoplastic $\mathrm{T}$ cells with immunoregulatory activity may add to our understanding of the regulatory mechanisms in the normal immune system (19). Because T-cell malignancies are homogeneous, "clonal" outgrowths of a particular T-cell, they enable one to perform immunoregulatory studies at the clonal level $(1,5,7,18-20)$. In the present study we analyzed the helper activity on T-cell-dependent Ig synthesis by normal B cells delivered by a series of seven neoplastic $\mathrm{T}^{+}$ cell populations. Helper activity was tested in the PWM-driven system and in a culture system in which exogenous IL-2 was present, and the requirement for IL- 2 production by the helper $T$ cells was bypassed (8).

The neoplastic $\mathrm{T}^{+}$cells of three out of seven patients in this series had helper activity on both PWM- and IL-2-induced Ig synthesis. The neoplastic $\mathrm{T}^{+}$cells of one of these patients (patient 2) even had stronger helper activity than normal $\mathrm{T}^{+}$cells on a per cell basis in the PWM-driven system. The $\mathrm{T}^{+}$cells of the remaining four patients (patients 4-7) did not provide helper activity on PWM-driven Ig synthesis, but showed good helper activity on IL-2-driven Ig synthesis. Helper activity on PWMdriven Ig synthesis correlated with the capacity of the neoplastic $\mathrm{T}^{+}$cells of patients $1-3$ to produce IL-2 in response to PWM stimulation. Table IV summarizes the immunological findings in this series of patients. In patients 2 and 3 the functional activities, IL-2 production and helper activity on PWM-driven Ig synthesis, were associated with hypergammaglobulinemia. No preference in helper activity on IgM or IgG production was observed with these neoplastic $\mathrm{T}^{+}$cells, although in patients 2 and 3, isotype-specific hypergammaglobulinemia existed for IgM, or IgA, and IgG, respectively (data not shown). Although IgA immune complexes and transiently elevated serum IgA were noticed in patient 6 , no preference for IgA-specific helper activity could be demonstrated with the tumor cells of this patient (data not shown).

Four of the patients suffered from T-PLL. Our results demonstrate that the neoplastic $\mathrm{T}^{+}$cells in two out of four T-PLL patients are mature, functionally competent $\mathrm{T}$-helper cells that produce IL- 2 and proliferate in response to T-cell mitogens. The T-PLL cells in patients 5 and 6 only provided help on IL-2driven Ig synthesis. To our knowledge this is the first report on immunoregulatory activities of T-PLL cells. Our results, together with the finding that in the majority of T-PLL patients the neoplastic $T$ cells had a mature helper phenotype (21), indicate that the leukemic $\mathrm{T}$-prolymphocytic cells are derived from relatively mature normal T-helper cells. It has been reported that in some, but not all, Sézary syndrome patients the malignant $\mathrm{T}^{+}$cells have helper activity on PWM-induced Ig synthesis $(5,19,22)$. In a series of seven Sézary patients tested in our laboratory, no helper activity could be found in the PWM-driven system delivered by neoplastic T cells (22). The tumor cells of only one of those patients (patient 6 in this study) had helper activity on IL-2-driven Ig synthesis.

In a previous study, it was shown that the failure of $\mathrm{T}^{+}$cells of patient 4 to provide help in the PWM-driven system indeed was due to a failure to produce IL-2 in that system. The lack of helper activity in the PWM system could be overcome by the addition of IL-2 and was not caused by suppressive effects of

Table IV. Immunological Findings in a Series of T4 $4^{+}$Neoplasms

\begin{tabular}{lllll}
\hline & & \multicolumn{2}{l}{ Helper activity } & \\
\cline { 3 - 4 } Patient & $\begin{array}{l}\text { IL-2 } \\
\text { production* }\end{array}$ & $\begin{array}{l}\text { PWM- } \\
\text { driven }\end{array}$ & $\begin{array}{l}\text { IL-2- } \\
\text { driven }\end{array}$ & $\begin{array}{l}\text { Hypergamma- } \\
\text { globulinemia }\end{array}$ \\
\hline 1. T-PLL & + & + & + & $-\ddagger$ \\
2. T-PLL & + & + & + & + \\
3. T-CLL & + & + & + & + \\
4. CT-CLL & - & - & + & $-\ddagger$ \\
5. T-PLL & - & - & + & $-\ddagger$ \\
6. Sézary & - & - & + & $-\ddagger$ \\
7. T-PLL & - & - & + & $-\ddagger$
\end{tabular}

* PWM-induced IL-2 production.

¥ In patients 1 and 4-7, Ig serum levels were within normal limits. 
PWM on the neoplastic $\mathrm{T}^{+}$cells (Miedema et al., submitted for publication).

The results of the analysis of the helper activities exerted by the neoplastic $\mathrm{T}^{+}$cells of this series of patients extend our previous studies on the role of IL- 2 in T-cell-dependent Ig synthesis (8). The finding that only $\mathrm{T}^{+}$cells, which produce IL-2 in response to PWM, have helper activity in the PWM-driven system, is in agreement with the hypothesis that IL-2 production is a strict requirement for PWM-induced Ig synthesis. On the other hand, the finding that $\mathrm{T}^{+}$cells, which themselves do not produce IL-2, are fully capable of supporting B-cell differentiation in the presence of exogenous IL-2, confirms that IL-2 is actually involved, and probably acts in concert with other T-cell-derived factors on activated B cells that bear IL-2 receptors (23). It has been shown in the mouse system that IL-2 induces the release of B-cell growth and differentiation factors by T-helper cells (24).

Our findings indicate that IL-2 production and the capacity to provide helper activity are two distinct T-cell properties. Until now, $T$ cell populations that provide helper activity on PWMdriven Ig synthesis without IL-2 production have not been found. Human T-cell clones have been described, however, that produced large amounts of IL-2 but had no antigen-specific helper activity, whereas other clones had strong helper activity but produced minimal amounts of IL-2 (10). It can be concluded that the use of both the IL-2- and the PWM-driven system in the study of immunoregulatory T-cell activities in health and disease enables one to separately study IL-2 production and the ability of the $\mathrm{T}$ cells to produce helper factors for B-cell differentiation.

\section{Acknowledgments}

We are grateful to Dr. E. Ritz (Department of Nephrology, University Hospital, Heidelberg, Federal Republic of Germany), Dr. J. W. Smit (Department of Hematology, University Hospital, Groningen, The Netherlands), Dr. I. R. Samaratunga (Department of Pathology, Farnborough Hospital, Orpington, United Kingdom), and Dr. J. Stork (Stichting Ziekenhuis Amstelveen, The Netherlands), for letting us study their patients and for collaboration. We are indebted to Dr. Lucien A. Aarden for his generous gift of purified IL-2.

This work was supported by grant CLB 80-2 of the Koningin Wilhelmina Fonds/Netherlands Cancer Organization.

\section{References}

1. Broder, S., R. L. Edelson, M. A. Lutzner, D. A. Nelson, R. P. McDermott, M. E. Durim, C. K. Goldman, B. D. Meade, and T. A. Waldmann. 1976. Sézary syndrome: malignant proliferation of helper T cells. J. Clin. Invest. 58:1297-1306.

2. Foon, K. A., F. Naiem, A. Saxon, R. Stevens, and R. P. Gale. 1981. Leukemia of T-helper lymphocytes: clinical and functional features. Leukemia Res. 5:1-10.

3. Gramatzki, M., M. F. Dolan, A. S. Fauci, J. A. Maples, G. D. Bonnard, and D. M. Strong. 1982. Immunological characterization of a helper T-cell lymphoma. Blood. 59:702-708.

4. Siegal, F. P., and M. Siegal. 1977. Enhancement by irradiated T cells of human plasma cell production: dissection of helper and suppressor functions in vitro. J. Immunol. 118:642-647.

5. Waldmann, T. A., W. C. Greene, P. S. Sarin, C. Saxinger, D. W. Blayney, W. A. Blattner, C. K. Goldman, K. Bongiovanni, S. Sharrow, J. M. Depper, W. Leonard, T. Uchiyama, and R. C. Gallo. 1984. Functional and phenotypic comparison of human $\mathrm{T}$ cell leukemia/lymphoma virus positive adult T-cell leukemia/lymphoma with HTLV-I negative Sézary leukemia and their distinction using anti-Tac. J. Clin. Invest. 73: 1711-1718.
6. Yamada, T. 1983. Phenotypic and functional analysis of leukemic cells from 16 patients with adult T-cell leukemia/lymphoma. Blood. 61: 192-199.

7. Miedema, F., F. G. Terpstra, J. W. Smit, S. Daenen, W. Gerrits, U. Hedge, E. Matutes, D. Catovsky, M. F. Greaves, and C. J. M. Melief. 1984. Functional properties of neoplastic $T$ cells in adult $T$-cell lymphoma/leukemia patients from the Caribbean. Blood. 63:477-481.

8. Miedema, F., J. W. van Oostveen, R. W. Sauerwein, F. G. Terpstra, L. A. Aarden, and C. J. M. Melief. 1984. Induction of immunoglobulin synthesis by Interleukin- 2 is $\mathrm{T}^{+} 8^{-}$cell dependent. A role for IL-2 in the pokeweed mitogen-driven system. Eur. J. Immunol. 15:107-112.

9. Sauerwein, R. W., W. G. J. van der Meer, A. Dräger, and L. A. Aarden. 1984. Interleukin-2 induces T-cell-dependent IgM production in human B cells. Eur. J. Immunol. 15:611-616.

10. Lamb, J. R., E. D. Zanders, M. Feldmann, P. Lake, D. D. Eckels, J. N. Woody, and P. C. Beverley. 1983. The dissociation of interleukin2 production and antigen-specific helper activity by clonal analysis. Immunology. 50:397-405.

11. Vyth-Dreese, F. A., H. J. van der Reyden, and J. E. de Vries. 1982. Phorbol-ester-mediated induction and augmentation of mitogenesis and interleukin-2 production in human T-cell lymphoproliferative disease. Blood. 60:1437-1446.

12. Van Oers, M. H. J., W. P. Zeijlemaker, and P. Th. A. Schellekens. 1977. Separation and properties of EA-rosette-forming lymphocytes in man. Eur. J. Immunol. 7:143-150.

13. Reinherz, E. L., and S. F. Schlossman. 1980. The differentiation and function of human T lymphocytes. Cell. 19:821-827.

14. Reinherz, E. L., P. C. Kung, J. M. Pesando, J. Ritz, G. Goldstein, and S. F. Schlossman. 1979. Ia determinants on human T-cell subsets defined by monoclonal antibody. J. Exp. Med. 150:1472-1482.

15. Thomas, Y., L. Rogozinski, O. Irigoyen, H. S. Shen, M. A. Talle, G. Goldstein, and L. Chess. 1982. Functional analysis of human T cell subsets defined by monoclonal antibodies. V. Suppressor cells within the $\mathrm{OKT}^{+}$population belong to a distinct subset. J. Immunol. 128 : 1386-1390.

16. Haynes, B. F., P. Bunn, D. Mann, C. Thomas, G. S. Eisenbarth, J. Minna, and A. S. Fauci. 1981. Cell surface differentiation antigens of the malignant $\mathrm{T}$ cells in Sézary syndrome and Mycosis Fungoides. $J$. Clin. Invest. 67:523-530.

17. Miedema, F., P. A. T. Tetteroo, W. G. Hesselink, G. Werner, H. Spits, and C. J. M. Melief. 1984. Both Fc receptors and LFA-1 on human $\mathrm{T} \gamma$ lymphocytes are required for antibody-dependent cellular cytotoxicity (killer cell activity). Eur. J. Immunol. 14:518-523.

18. Rümke, H. C., F. Miedema, I. J. M. ten Berge, F. G. Terpstra, H. J. van der Reyden, R. J. van de Griend, H. G. de Bruin, A. E. G. Kr. von dem Borne, J. W. Smit, W. P. Zeijlemaker, and C. J. M. Melief. 1982. Functional properties of $\mathrm{T}$ cells in patients with chronic $\mathrm{T} \gamma \mathrm{lym}$ phocytosis and chronic T-cell neoplasia. J. Immunol. 129:419-426.

19. Broder, S., T. Uchiyama, and T. A. Waldmann. 1979. Neoplasms of immunoregulatory cells. Am. J. Clin. Pathol. 72(Suppl.):724-731.

20. Miedema, F., F. G. Terpstra, J. W. Smit, J. P. W. van der Veen, and C. J. M. Melief. 1985. T $\gamma$ lymphocytosis is clinically nonprogressive but immunologically heterogeneous. Clin. Exp. Immunol. 61:440-449.

21. Catovsky, D., A. Wechsler, E. Matutes, R. Gomez, G. Bourikas, M. Cherchi, E. O. Pepys, M. B. Peys, T. Kitani, A. V. Hoffbrand, and M. F. Greaves. 1982. The membrane phenotype of T-prolymphocytic leukemia. Scand. J. Haematol. 29:398-404.

22. Miedema, F., R. Willemze, F. G. Terpstra, W. A. van Vloten, C. J. L. M. Meyer, and C. J. M. Melief. 1984. Regulatory activity of neoplastic $\mathrm{T}$ cells in Sézary syndrome on in-vitro immunoglobulin production. Leukemia Res. 8:873-884.

23. Mingari, M. C., F. Gerosa, G. Carra, R. S. Accolla, A. Moretta, R. H. Zubler, T. A. Waldmann, and L. Moretta. 1984. Human interleukin-2 promotes proliferation of activated B cells via surface receptors similar to those of activated T cells. Nature (Lond.). 312:641-643.

24. Inaba, K., A. Granelli-Piperno, and R. H. Steinman. 1983. Dendritic cells induce $\mathrm{T}$ lymphocytes to release $\mathrm{B}$ cell-stimulating factors by an Interleukin 2-dependent mechanism. J. Exp. Med. 158:2040-2057. 